\title{
English Medium Instruction and the Internationalization of Higher Education in Latin America: A Case Study from a Colombian University
}

Inglés como medio de instrucción y la internacionalización de la educación superior en Latinoamérica: un estudio de caso en una universidad colombiana

Inglês como meio de instrução e a internacionalização da educação superior na América Latina: um estudo de caso em uma universidade colombiana

Isabel Tejada-Sanchez

https://orcid.org/0000-0002-4008-8057

Universidad de Los Andes, Colombia mi.tejadaı_@uniandes.edu.co

Mario Molina-Naar https://orcid.org/0000-0002-8717-4390

Universidad de Los Andes, Colombia j.molina@uniandes.edu.co

Received: 28/02/2020

Accepted by peers: 31/08/2020
Sent to peer review: $28 / 02 / 2020$

Approved: 18/09/2020

DOI: 10.5294/laclil.2020.13.2.8

To reference this article (APA) / Para citar este artículo (APA) / Para citar este artigo (APA)

Tejada-Sánchez, I., \& Molina-Naar, M. (2020). English medium instruction and the internationalization of higher education in Latin America: A case study from a Colombian university. Latin American Journal of Content \& Language Integrated Learning, 13(2), 339-367. https:// doi.org/10.5294/laclil.2020.13.2.8 
ABSTRACT. This study discusses the implementation of English medium instruction (EMI) at a Colombian university. First, the paper reviews the rise of EMI in the internationalization of higher education. Second, it illustrates how one university incorporated EMI as part of an internationalization process. Third, it identifies the perceptions that a group of administrators, faculty, and students have regarding the EMI initiative. Questionnaires, semi-structured interviews, and document analysis were conducted. Findings suggest that EMI is tied to the structuring of an internationalization office, curricular reforms, and English language learning support. Participants' perceptions are associated with their imaginaries, identities, experiences, and obligations in relation to the English language. The study concludes that the implementation of EMI within the internationalization of universities is inevitable, yet a sustainable EMI strategy requires contextual awareness and articulation amongst its participants.

Keywords (Source: Unesco Thesaurus): English-medium instruction; internationalization; university; higher education; Colombia.

RESUMEN. Este estudio analiza la implementación del inglés como medio de instrucción (EMI, por sus siglas en inglés) en una universidad colombiana. Primero, el artículo revisa el auge de EMI en la internacionalización de la educación superior. Segundo, ilustra cómo una universidad incorporó EMI como parte de un proceso de internacionalización. Tercero, identifica las percepciones que tiene un grupo de administrativos, profesores y estudiantes con respecto a la iniciativa de EMI. Se realizaron cuestionarios, entrevistas semiestructuradas y análisis de documentos. Los hallazgos sugieren que EMI está vinculado a la estructuración de una oficina de internacionalización, reformas curriculares y al apoyo al aprendizaje del inglés. Se halló que las percepciones de los participantes están asociadas a sus imaginarios, identidades, experiencias y obligaciones en relación con el inglés. El estudio concluye que la implementación de EMI dentro de la internacionalización de las universidades es inevitable; sin embargo, una estrategia de EMI sostenible implica una sensibilización sobre el contexto y una articulación entre sus participantes.

Palabras clave (Fuente: tesauro de la Unesco): Inglés como medio de instrucción; internacionalización; universidad; educación superior; Colombia.

RESUMO. Este estudo analisa a implementação do inglês como meio de instrução (EMI, por suas siglas em inglês) em uma universidade colombiana. Primeiramente, o artigo analisa a ascensão da EMI na internacionalização do ensino superior. Em segundo lugar, ilustra como uma universidade incorporou a EMI como parte de um processo de internacionalização. Em terceiro lugar, identifica as percepções que um grupo de administradores, professores e alunos têm em relação à iniciativa EMI. Foram realizados questionários, entrevistas semiestruturadas e análise documental. Os resultados sugerem que a EMI está ligada à estruturação de um escritório de internacionalização, reformas curriculares e apoio à aprendizagem de inglês. As percepções dos participantes foram associadas aos seus imaginários, identidades, experiências e obrigações em relação ao inglês. O estudo conclui que a implementação do EMI no âmbito da internacionalização das universidades é inevitável; no entanto, uma estratégia EMI sustentável implica a consciência do contexto e a articulação entre os seus participantes.

Palavras-chave (Fonte: tesauro da Unesco): Inglês como meio de instrução; internacionalização; universidade; ensino superior; Colômbia. 


\section{Introduction}

The definition of English medium instruction (EMI) varies according to the context in which it is adopted. For the purposes of this study, EMI is acknowledged as a practice in which

non-language courses in for instance medicine, physics or political science are taught in English, to students for whom it is a foreign [but also a first, second, or additional] language. As often as not, it is also taught by a lecturer who does not have English as a first language (L1). (Hellekjaer, 2010, p. 11)

The role of language in EMI is very different from that of language within other concepts, such as English for Academic Purposes (EAP); while EAP is characterized by its focus on language learning, EMI mainly aims at the achievement of content goals (Airey, 2016; Macaro, 2018). The absence of a language-driven view in EMI has caused criticism, as it has been believed to negatively affect content learning via a second language (L2), diminish the role of local and national languages, and undermine proper and fair assessment procedures in universities (Shohamy, 2013).

The growth of EMI often relates to the internationalization objectives, financial goals, and expected ranking positions of universities across the globe. A study by Morell et al. (2014) suggested that EMI was crucial for achieving the internationalization of their university in Spain. Thus, this Higher Education Institution (HEI) is now offering many English-taught programs (ETPs), as well as incentives for those who teach them. In Taiwan, the Ministry of Education established an internationalization policy that involves the inclusion of EMI in HEIs, which is often an indicator to measure the quality of education (Huang, 2018). Middle Eastern HEIs in nations such as Saudi Arabia or Dubai are creating partnerships with English-speaking universities from the United States and the United Kingdom in order to attract international students and investment, as well as to be accredited (Altbach \& Knight, 2007).

Implementing EMI for the sole purpose of internationalizing HEIs poses challenges to faculty members and students. Duong and Chua 
(2016) reported that, especially at the start of the project, the shifting to EMI in their university represented a great challenge, as some of the instructors lacked the necessary proficiency to use English to teach their courses. Moreover, research carried out in an undergraduate business ETP in Taiwan examined the experiences and perceptions of four students who revealed dissatisfaction and resistance towards EMI (Huang, 2018). They felt that EMI courses were undemanding, that the pedagogical strategies used by the instructors were demotivating and ineffective, and that, contrary to what the university claimed, the quality of the education offered was far from exceptional.

As for Latin America, there is still a dearth of case scenarios on EMI. Martinez (2016) anticipated that the implementation of EMI in Brazilian HEIs would bring challenges related to language, culture, and institutional management. The author also acknowledged that, while EMI in Brazil is still at its earliest stages of development, it has many lessons to learn from other contexts around the world. Additionally, a study conducted in Colombia concluded that EMI provides opportunities for content and L2 learning; however, if not implemented properly, it may negatively impact the motivation and commitment of the participants. Thus, the authors recommend introducing clear pedagogical guidelines such as those for CLIL (Corrales et al., 2016).

Despite certain gaps and criticism outlined in the literature (Bonilla \& Tejada, 2016), defining the role of English teaching in Colombian education has become a priority for the Government in recent decades. According to the English Proficiency Index (EPI) (Education First, 2017), Colombia ranked $51^{\text {st }}$ in the EPI out of a total of 80 countries, and $11^{\text {th }}$ in Latin America. Thus, English has been positioned as a crucial component of the national internationalization strategy in the country. This is revealed by the Colombia Bilingüe 2014-2018 program, which promotes the development of "human capital" in the country through the teaching and learning of English (Ministerio de Educación Nacional, n.d.).

In the same vein, Cronquist and Fiszbein (2017) identify three key factors that need to be ensured to achieve successful English language learning in the Latin-American region: 1) continuity, 2) monitoring and evaluation, and 3) addressing the lack of "sufficient quality teachers." As such, a key recommendation emerging from these findings is the 
promotion of internationalization strategies such as the exchange of students and teachers with English-speaking countries (Education First, 2017). Similarly, Gazzola, and Didriksson (2008) stress that the lack of English proficiency continues to be one of the greatest gaps in Latin America, which limits employment opportunities, competitiveness, and attractive opportunities for foreign investment in the region. Such findings directly concern the role of HEIs as platforms where the socio-economic development of the region is forged.

Until now, internationalization has been approached as an activity-oriented, instrumental action and not as an integral process-based approach that aims to develop competencies and increasing quality (Gacel-Ávila, 2003; de Wit, 2011). This process has also led to some intricate conceptualizations. One of these includes envisioning the internationalization of the curriculum (IoC) as the "the incorporation of an international and intercultural dimension into the preparation, delivery, and outcomes of a program of study" (Leask, as cited in Beelen \& Jones, 2015, para. 12). Another conceives internationalization at home (IaH), as a "set of instruments and activities 'at home' that aim to develop international and intercultural competences in all students" (Beelen \& Jones, 2015, para. 25). Regardless of the approach, English appears to have an indisputable role in HEI internationalization as the most frequently used language of research dissemination (Crystal, 2003).

Certainly, EMI underlies the rise of internationalization in the 21st century as a key strategy in the university context (de Wit, 2011; Dafouz \& Smit, 2020). Thus, many HEIs in non-English-speaking contexts assume that the learning of English in academic programs could give students and scholars a better footing within the international academic community (Hamp-Lyons, 2011). In these approaches to internationalization, a debate concerning "a disconnect between some of the practical policies of the institution and government, and the voice of the institutional leader and the students" (Teasdale, 2017, p. 142) has been initiated.

This disconnect has been associated with the notions of social imaginary (Taylor, 2002) and global imaginary (Stein et al., 2016) of what internationalization should be about. Such imaginaries refer to "the organizing structure of shared understanding that makes legible or illegible certain relationships and practices within a given community" 
(p. 2). Some of these claims imply the need for articulation, collaboration, relationships, networks, and communication among the stakeholders, as well as the need to acknowledge unequal power relations where only a handful of institutions, governments, and entities are able to put internationalization into practice (Rizvi, 2007).

Imaginaries and identities in English language teaching and learning have extensively been addressed. However, in the era of internationalization, these notions need more attention in order to reduce the institutional disconnect described above. For Omoniyi and White (2006), language identity is constructed within established contexts that may vary from one to another and informs communicative exchanges and social relationships. Based on conceptualizations from sociology and philosophy, Valencia-Cabrera (2017) defines imaginaries within language teaching and learning as: "common understandings of how individuals imagine their own social existence and that of others" (p. 26). In a way, these common understandings are mediated through social and technological interactions that entail "individuals' understandings of their place in the world among others, their expectations, their envisioned futures, and the norms and values associated with these" (p. 26).

On the other hand, imaginaries and identities in EMI settings have hardly been addressed, yet the issue is emerging in the literature as EMI spreads across the globe. There has been some scholarly work in relation to EMI practitioner identity reconfiguration and the needs of EMI teachers according to their context (Soren, 2013), but not in relation to all the stakeholders within an internationalization strategy.

Competitive performance in English in the global academic and professional market is not an easy feat to achieve for the whole of the HEI community, especially in non-English speaking countries. In Latin America, the challenges relate to issues of the Global South, such as low teacher training quality, insufficient resources, and inconsistency in language education policies, as well as the need to produce a research and development agenda that involves the local community and context (Novelli \& Lopes-Cardozo, 2008). However, Latin American HEIs have undergone multiple changes with respect to internationalization, including the promotion of academic quality, research and development, increased student and faculty mobility, greater 
funding opportunities, and the incorporation of English as a language of instruction.

The effectiveness of EMI in HEI still appears to be considerably underexplored. A systematic review by Macaro et al. (2018) described the rapid expansion of EMI across university curricula and pinpointed its potential drawbacks. As such, they concluded that "current EMI implementation produces more challenges than opportunities" (p. 68). Despite this, they foresee an inevitable growth of EMI in universities, and maintain that the corollaries of implementing such initiatives without reflecting on their implications may be serious. Therefore, they call for adequate reforms, preparation, and resources before adopting EMI.

Evidence in the literature shows that EMI has appeared as an attempt to increase internationalization; in this regard, it often emerges as a university-wide administrative decision in which not all the participants (administrators, faculty, and students) are directly involved. Thus, inquiring about their perceptions is crucial to understanding the implications of such processes as well as their impact on the institution's internationalization and on the attainment of students' academic and professional goals. Thus, the guiding questions of this study are:

RQ1) How does a Colombian HEI attempt to fulfil internationalization objectives and contribute to students' long-term academic and professional purposes through EMI?

RQ2) What are the perceptions that a group of administrators, faculty, and students have regarding an EMI initiative at a Colombian HEI?

\section{Method}

This is a descriptive and interpretive single case study, which attempts to understand how an EMI initiative has been conducted and perceived within a private HEI. To do this, official documentation and policy guidelines as well as participants' perceptions (students, faculty, and administrators) were explored. For the latter, a questionnaire and semi-structured interviews were conducted. A case study design was chosen, as it allows the researchers to delve into the participants' involvement, understanding, and reception of the institutional 
practices concerning EMI and internationalization (Yin, 2009; Merriam \& Tisdell, 2015).

\section{Context}

This study was conducted at a private Colombian university, which is among the highest-ranking in the region (Times Higher Education, 2019). As stated in its institutional development program, the university aims to achieve national and international visibility through high-quality academic and research work by promoting excellence, interdisciplinarity, diversity, ethics, and strong language competencies among its students, faculty, and alumni.

The language department at this university has played a major role for over two decades, offering foreign language courses in English, French, German, Italian, Portuguese, Japanese, Chinese, and Spanish. Currently, undergraduate students must fulfil three L2 requirements: 1) academic reading comprehension in English; 2) L2 "mastery," which students can complete in English or other languages such as French, German, Italian, and Portuguese; and 3) passing an EMI course.

As of the second semester of 2019, over 35 EMI courses were offered in different areas. More than 800 students were registered in these courses; most of them were Colombian, although there were also exchange students from France, Mexico, and the United States. The professors who teach these courses are experts in the subject and are either Colombian or of other nationalities. The EMI course criteria approved by the language department in 2017 state that, besides achieving the content area objectives, the students are expected to enhance their receptive and productive English skills, acquire academic and content vocabulary, and engage in academic interactions in international and intercultural contexts. Instructors can opt to design or revise their EMI course syllabi with the support of the language department before they are sent to an advisory committee which decides whether the courses meet the set criteria.

\section{Participants}

The participants in this case study are divided into three groups: administrators and faculty, based on purposeful sampling, and students, 
following convenience sampling (Cohen et al., 2007). Administrators included four university leaders who make decisions and carry out pivotal actions for the implementation of English and the internationalization policy. The faculty participants included two teachers who participated in the implementation of the EMI initiative. One was an EFL teacher whose L1 was English and whose role was to support language learning aspects in an EMI course. The other one was an English-Spanish-L1 content teacher who taught an EMI course. The student group consisted of 121 undergraduate students enrolled in the EMI courses offered at the time of the study (see Table 1).

Table 1. Participants' profiles

Administrators $(A)$

Head - Language Department (A1)

Coordinator - English program (A2)

Head - Internationalization (A3)

Head - Mobility program (A4)

Faculty (F)

English Teacher L1-English (F1)

Content Teacher L1 English-Spanish (F2)

Students enrolled in EMI courses (S)

Source: Own elaboration.

\section{Data collection procedures}

In order to conduct this case study, different data sources were collected and analyzed in the first and second semesters of 2018. Participants agreed to take part in the study through informed consent. The data collection methods used were the following:

\section{Document analysis}

A review of institutional documentation of this HEI was conducted in order to identify and contextualize its internationalization strategy, English language policy, EMI initiative, and the practices derived from these. Documentation was accessed through the university's official 
website and upon request to administrative parties. The revision of each document consisted of identifying specific segments and declarations that referred to the previously mentioned topics. The documents examined were: 1) the 2016-2020 Institutional Development Plan (IDP); 2) the internationalization strategy; 3) the foreign language policy and requirements; and 4) the EMI guidelines.

\section{Semi-structured interviews}

As this study is aimed at understanding the participants' perceptions, backgrounds, and experiences in relation to the EMI scenario, semi-structured interviews allowed the researchers to have a set of guiding core questions, as well as the flexibility to ask follow-up questions to clarify or elaborate throughout the conversation (Barkhuizen et al., 2013). These interviews were conducted with administrators and faculty in Spanish and English. The questions addressed three main themes: 1) the participants' history and experience at the HEI and with the English language; 2) their knowledge about institutional perspectives regarding English, the EMI initiative, and internationalization; and 3) their personal perspectives about the role of English and the EMI strategy in the world. Interviews were one-hour long, and they were fully transcribed; those conducted in Spanish were translated into English. All of the interviews were coded using a thematic analysis that identified both inductive (emerging from the data) and theoretical (deductively drawing on the literature review) themes (Braun \& Clarke, 2006).

\section{Questionnaires to students}

A 20-item, 5-point Likert-scale questionnaire was administered. The questionnaire included four constructs (see Table 2) based on the EMI guidelines and the internationalization aims of this HEI. The questionnaire also included open questions asking about the students' impressions and experiences with the EMI initiative. Regarding validity, the questionnaire underwent peer revision by EMI professors and two language experts. In addition, the researchers e-mailed the questionnaire to the students in two different academic periods of 2018, semester 1 and semester 2. The first was considered a pilot stage of the instrument. Therefore, only responses from semester 2 were taken into account for this study. The instrument detailed its purpose and use 
in order to ensure its reliability and ethical implications (Cohen et al. 2007). The questionnaire was sent to all the students enrolled in an EMI course; however, only around $15 \%(n=121)$ of the total population completed it. Although the questionnaire was provided in English and Spanish, 93.5\% answered the Spanish version. Open comments were also coded using thematic analysis.

Table 2. Questionnaire constructs

\begin{tabular}{|l|c|}
\hline \multicolumn{1}{|c|}{ Construct } & Questions \\
\hline Content knowledge development through EMI & 4 \\
\hline Critical thinking through EMI & 2 \\
\hline English development \& use through EMI & 8 \\
\hline Belonging to an academic international community & 6 \\
\hline
\end{tabular}

Source: Own elaboration.

\section{Results}

Findings for both RQs emerge from the triangulation of the data. The analysis of official documents and interviews addresses RQ1; the interviews and questionnaire address RQ2.

\section{Research question 1}

Three main themes emerged regarding the achievement of internationalization objectives and the promotion of students' long-term academic and professional purposes through EMI in this HEI (summarized in Table 3, along with data source). These themes are inextricably related and seem to follow a hierarchical order where Theme 1 is the major strategy that encompasses actions described in Themes 2 and 3. 
Table 3. Emergent themes for RQ1

\begin{tabular}{|l|l|}
\hline \multicolumn{1}{|c|}{ Theme } & \multicolumn{1}{c|}{ Data source } \\
\hline $\begin{array}{l}\text { 1. Structuring an internationalization } \\
\text { office }\end{array}$ & - IDP \\
$\begin{array}{l}\text { 2. Developing an adaptive } \\
\text { curriculum reform }\end{array}$ & - Internationalization strategy \\
$\begin{array}{l}\text { 3. Reinforcing English language } \\
\text { learning (ELL) environments }\end{array}$ & - requirements \\
\hline
\end{tabular}

Source: Own elaboration

\section{Structuring an Internationalization Office (IO)}

In 2016, an academic and administrative office that handles the internationalization processes of the university was established. This office leads faculty and student mobility, cooperation, institutional visibility, and research development so that the university can "reach a higher degree of internationalization where high quality programs and joint projects with other universities and international organizations are held" (IDP. 2.1, p. 18).

As seen in the following statement, this office aims to enhance the HEI's impact at the social, local, and international levels:

To facilitate the construction of a broad vision of the national and international context, in the training and research processes of the University, through the promotion of intercultural competencies and knowledge transfer thus enhancing the social and international impact of the quality and innovation of the University. (Universidad de los Andes, 2016).

Likewise, the IO promotes academic exchange, intercultural competencies, and cooperation within local and international contexts. Currently, the university has around 275 partner HEIs within Colombia and around the world; cooperation is fostered through these partnerships in the form of student and faculty exchange. Through these activities, the importance of learning English is highlighted in the institutional mission, in which the university intends to "strengthen the presence of the English language within the University programs according to the nature of these" (IDP. 1.4.4, p. 14).

Even though the official establishment of the IO occurred in 2016, this HEI has been conducting internationalization activities from years 
before. In this regard, A2 states that "it traces way back, but now you can feel the push." Also, hiring international scholars or bringing visiting professors to teach courses through the medium of English (either permanently or temporarily) has been a regular practice for several years. However, A1 maintains that such practices used to be problematic for two reasons: "Sometimes these courses became lifesavers for faculty who wouldn't want to speak Spanish" and, also, these implied an "economic incentive for the academic departments," since it is part of the dynamics of a private HEI. In line with these practices, F2 highlights that enacting internationalization through EMI courses should be negotiated within each department in order to take into account their particular needs.

The creation of the IO seems to lead to an increasing dialogue with a global community, and not only among scholars. Nonetheless, among the participants, this action is deeply linked to worldwide university standards. In this respect, F2 asserts that "[internationalization] comes from an evaluation provided to attain a ranking... so high-ranked administrative stakeholders made the decision that this was an issue we had to work on." He also adds that "to route this strategy based on the rankings... can be a problem since this can divert the momentum and not connect with internal needs." Regarding this, the head of the office (A3) comments:

[internationalization] is made up of those minor details and processes; this means that, if you make the university more international, the whole world opens in front of you. So, the world opens for you, and you open yourself to the world... but obviously the needs [of each context] are always different.

This perspective on internationalization shows the necessity of being aware of the local context when conducting these initiatives.

\section{Developing an adaptive curriculum reform}

Alongside the constitution of an IO, this university has reformed its curriculum, making it more systemic and flexible, leading to substantial academic and administrative actions: 1) flexible scheduling, adaptive to different academic calendars worldwide, instead of only two semesters per year; 2) adjustments and innovations in general education courses, incorporating intensive exposure to English and 
technology-enhanced learning; and 3) development of $21^{\text {st }}$-century skills across the curriculum.

It is worth noting that a previous curriculum reform in the ELL program took place in the 1990s, and it was referred to as a "major" top-down "change" (A2; A4). This reform included the TOEFL exam as a requirement to graduate, a decision that raised many issues:

I was already in this office when the university decided about the TOEFL... and it was terrible! Of course many students spoke the language when they got close to graduation, but there was a moment where I had to call the TOEFL (sic) every day to corroborate the scores. (A4)

This brought about a change in the ELL program in which language courses on skills other than reading (e.g., speaking and writing) were introduced as part of the new curriculum: "we learned about this at the same time as the students... so this led us to a first reform in 99... and then another one in 2002... where it basically stabilized." (A2).

The present reform was introduced in 2017 in the ELL program, which currently serves 2,670 undergraduate students. To focus on ELL and help students reach language proficiency in a shorter period of time, this initiative entailed increasing the number of hours of instruction in the program from 465 to 552, including both face-to-face and online work in certain blended courses. Offering courses that integrate the different language skills, as well as courses on academic writing and speaking for professional purposes are some of the changes that the ELL program underwent.

\section{Reinforcing ELL Environments}

This theme focuses on the ways this HEI has fostered environments that aim to support ELL. In 2015, the Language Department opened the English tutoring center for students seeking language support. In her interview, F1 reported that the center is "a great step forward," and that "it's really nice to know that, when you're giving a challenging assignment... to the weaker students... you're also offering... you have somewhere to go, and you have someone to help you... I think it's a huge advantage..."

Also, after EMI courses were introduced in 2017 as an L2 graduation requirement, the language department developed a strategy to support 
EMI teachers with course design, syllabus adjustments, and team teaching with an English teacher (EMI strategy guidelines). Collaboration and team-teaching were also addressed in the interviews; specifically, F1 stated the following regarding the way the traditional lecture-style methodology is sometimes replaced by more student-centered activities: "[EMI courses] are a great opportunity because I do see students interacting in English... we're instituting, like 'Pair-Share' two or three times a class..."

Despite the support provided, the increasing number of EMI courses is a matter of concern among the faculty; both of them were apprehensive about the English level of certain students. F2, for example, said that, although it is important "to offer EMI courses... it is more important to offer English language courses for those students who need them." Likewise, F1 stated: "I see students seeing challenges in front of them, especially if they're still working on their English because they really need to use it to... make these connections that the university is sort of offering to them." For her part, A1 highlighted the importance of the language department in providing academic support to the students who take the EMI courses: "I believe that, if the internationalization of the university takes place, it is because it has a strong language department... and not only because English is spoken to fulfil a requirement." In a way, this last idea also seems to express concerns about the way in which EMI is being introduced in the HEI.

In fact, critical views about the role of English in relation to other languages and its impact on internationalization emerged in the interviews. F2 explicitly expressed his support for more "multilingualism" in this HEI: "It would be good to have a Department of the Middle East, a Department of South Asia, a Department of African Studies... more departments for Brazilian and Portuguese studies. I think that would be important, right?" However, he also added that "English is sort of a global lingua franca," and that "one of the elements of internationalization is to attract exchange students and international faculty, so English is necessary for that."

Despite their concerns about the students' English level and the top-down nature of decision making, the participants appear to believe that this HEI does need English, and more specifically EMI, in order to contribute to the students' ongoing development, both academically 
and professionally. This is in line with institutional initiatives that emerged as themes in the first research question, namely establishing an IO, fostering curriculum reforms, and providing more ELL opportunities for students.

\section{Research Question 2}

Participants' perceptions about EMI and internationalization were found to be shaped by three overarching and interrelated themes: imaginaries, identities, and institutional requirements. These themes proved to be interconnected threads to approach the goals of higher education, namely the pursuit of a career and the expectations about English in a globalized society.

\section{Imaginaries: English in a globalized professional and academic community}

Participants shared their views about what ELL and proficiency represents in their lives and in today's world. Their perceptions of an EMI initiative seem permeated by social, global, and socio-cultural imaginaries where the role of English in internationalization is equated with professional success. For instance, A2 suggests that knowing English implies professional opportunities and that lacking this knowledge might hinder them, saying:

I see... two things: One, that people have noticed that English opens doors for them... The moment they finish their studies..., English opens doors and gives them more opportunities. Two... their parents... know that they have needed English... and they do not want their children to suffer the same lack of the language.

For A1, English holds a privileged position compared to other languages, although this depends on the student's program and future career. Moreover, A1 argues that the English currently learned and spoken is somewhat a reduction of the language, a "tecnolect" communicated in English but restricted to academic settings, such as conferences and papers. A1 also stresses the importance of considering other languages at university, as part of an international academic ecosystem, stating:

In this university... there are fields where [learning English] is central... I do not want to relativize its importance, but I do want to 
highlight that its role varies across disciplines. I also want to emphasize that, in this department [the language department], English is definitely the most popular language, but it is not the only one.

Furthermore, the idea of English mastery being crucial is confirmed by some students in the questionnaire. When asked about their motivations to enroll in the EMI course (Figure 1), 26\% of students reported that the content interested them, $27 \%$ reported that they enrolled because they needed to fulfil the language requirement, and $27 \%$ declared that they took the EMI course simply to practice or improve their English. Moreover, when asked about what they would highlight about the EMI course, $21 \%$ of them stated that they were developing content knowledge, whereas 31\% said they were developing or strengthening their academic English. These findings are relevant to understanding students' perceptions of the role of English for them; it was unexpected that the primary reason students would take EMI courses would be practicing the language rather than learning about the content.

Figure 1. Content knowledge development through EMI

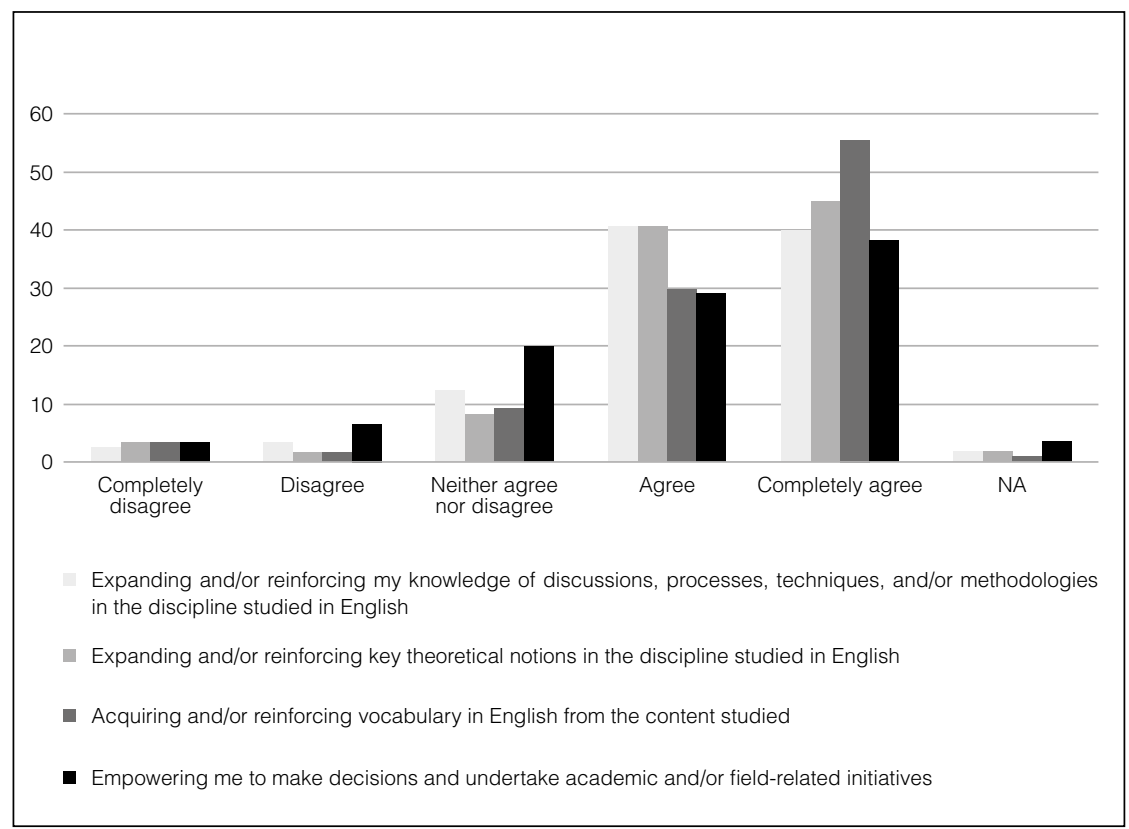

Source: Own elaboration. 


\section{Identities: English in their lives and experiences}

Participants' perceptions were shaped by their experiences with the language, family and social backgrounds, personal interests, and academic history. These perceptions favored to a greater or lesser extent their reception of the EMI scenario in tandem with internationalization.

In the administrators' group, perceptions towards the English language differ and are strongly connected to early education experiences. Participants reported being raised in bilingual environments in English or German, for example, as A2 and A3 report:

I am bilingual from an early age... so English was natural to me from a very young age... I entered [a bilingual school]; at that time, this school was only meant to welcome expatriates... (A2)

I learned English like "on the side"... I am bilingual in German. In my school from grade 5 they started the English courses... I have never lived in any English-speaking country, but for me it has been very important [to know English]. At the time of my doctorate in Germany, interestingly, I decided to write my dissertation in English. (A3)

From the participants' backgrounds, English is seen in a myriad of ways, either as "traumatic" (A1), as a natural commodity, or as a "necessity" (A2), and it is equated with the opportunities to travel the world and encounter this language as a lingua franca wherever you go: "we went on holidays with a passport very late in life, and these kids nowadays are traveling from so early... so they are encountering this language and other cultures very soon " (A2).

The participating faculty members reported that English had been an important element of their personal identities: F1 believes that not only being a native speaker but also having a thorough knowledge of the language has been helpful to her. F2 acknowledges that English has been present in his social interactions, formal education, and professional development throughout his life. He reports that, at an early age, he went from living in a bilingual context to being fully immersed in a trilingual environment where English had a major role. Despite the fact that he shares the same L1 and nationality with the local students, he identifies himself "as a foreigner" in his classes, which suggests that language history and use influences people's self-perceptions as both individuals and professionals. 
Among the students, over $60 \%$ reported having completed the university L2 requirement with English. Also, English appears to be relevant for them as well as permeate their identities and the way they perceive their world. One of the open-ended questions in the questionnaire asked about their motivations to enroll in an EMI course. Some students reported that they "loved English," felt that they "performed better in English" in their classes, thought that the course would be "more interesting in English than in Spanish," or they simply wanted "to practice the language." As some had gone to bilingual schools, one of them stated that she "missed speaking English" while another reported that English was "almost a second mother tongue" for her and that she has "lost opportunities to practice English" at the university.

The questionnaire also revealed that English, and more specifically EMI, has a major role in shaping the students' social practices and experiences. First, over $75 \%$ of the students believe that their EMI course fostered critical thinking and intercultural awareness, while $67 \%$ reported feeling empowered to make decisions in English (Figure 2).

Figure 2. Critical thinking through EMI

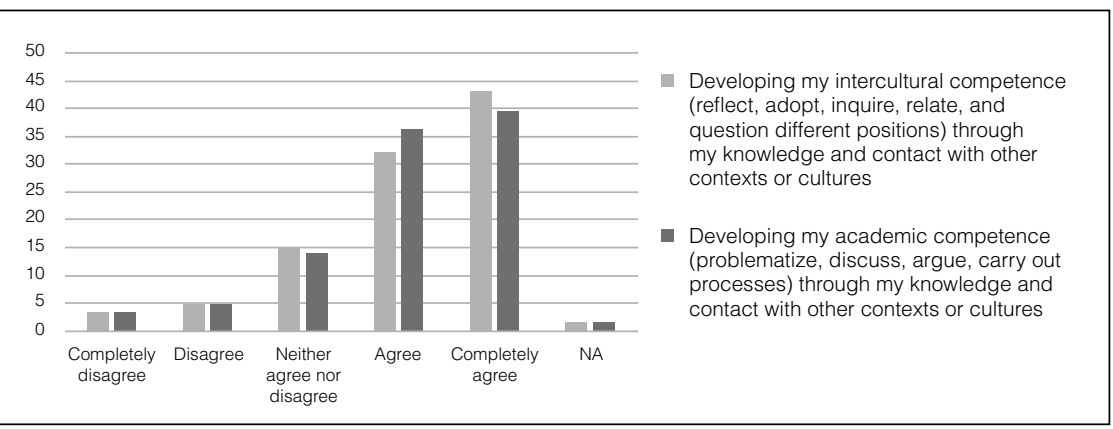

Source: Own elaboration.

Regarding the use of English, over $80 \%$ of the participants agree that the EMI experience provides the opportunity to reinforce and practice all language skills (Figure 3). However, the students do not perceive that the EMI courses provide them with opportunities for daily practice, even though they were dedicating considerable time to this language during the EMI course. When surveyed about the use of English on a daily basis, students' agreement with the statements diverged greatly from $30 \%$ to $70 \%$ (Figure 4). 
Figure 3. Practice and reinforcement of the language skills in English through the EMI course

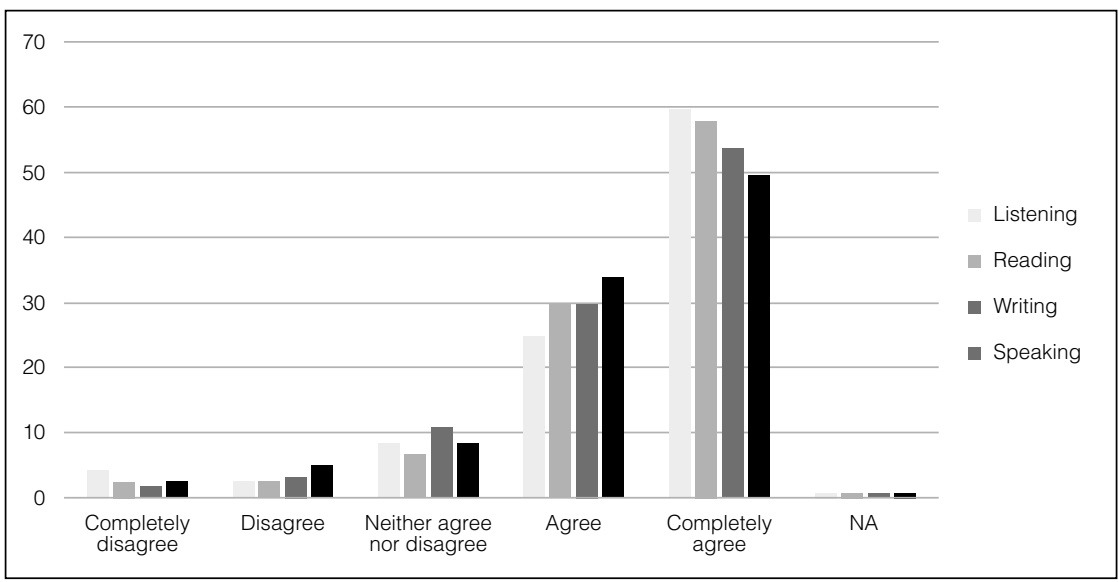

Source: Own elaboration.

Figure 4. English practice opportunities in EMI courses

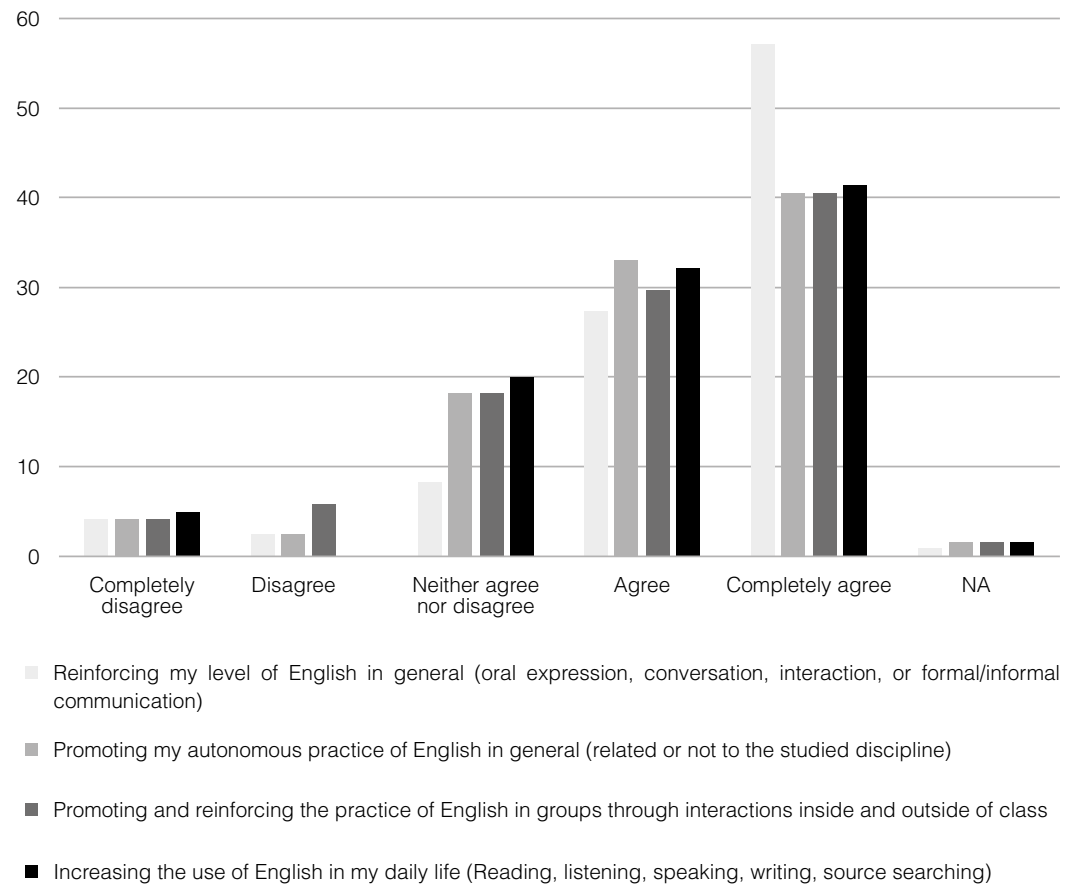

Source: Own elaboration. 
Finally, regarding the university's internationalization strategy, students mostly agree that the EMI experience is fostering international academic participation in their disciplines; nonetheless, the reactions regarding this construct were rather mixed, ranging from $57 \%$ to 75\% (Figure 5). Many chose the intermediate option, which may imply that students are not sure that the EMI initiative is providing opportunities for international participation in their disciplines, yet.

Figure 5. Belonging to an academic international community

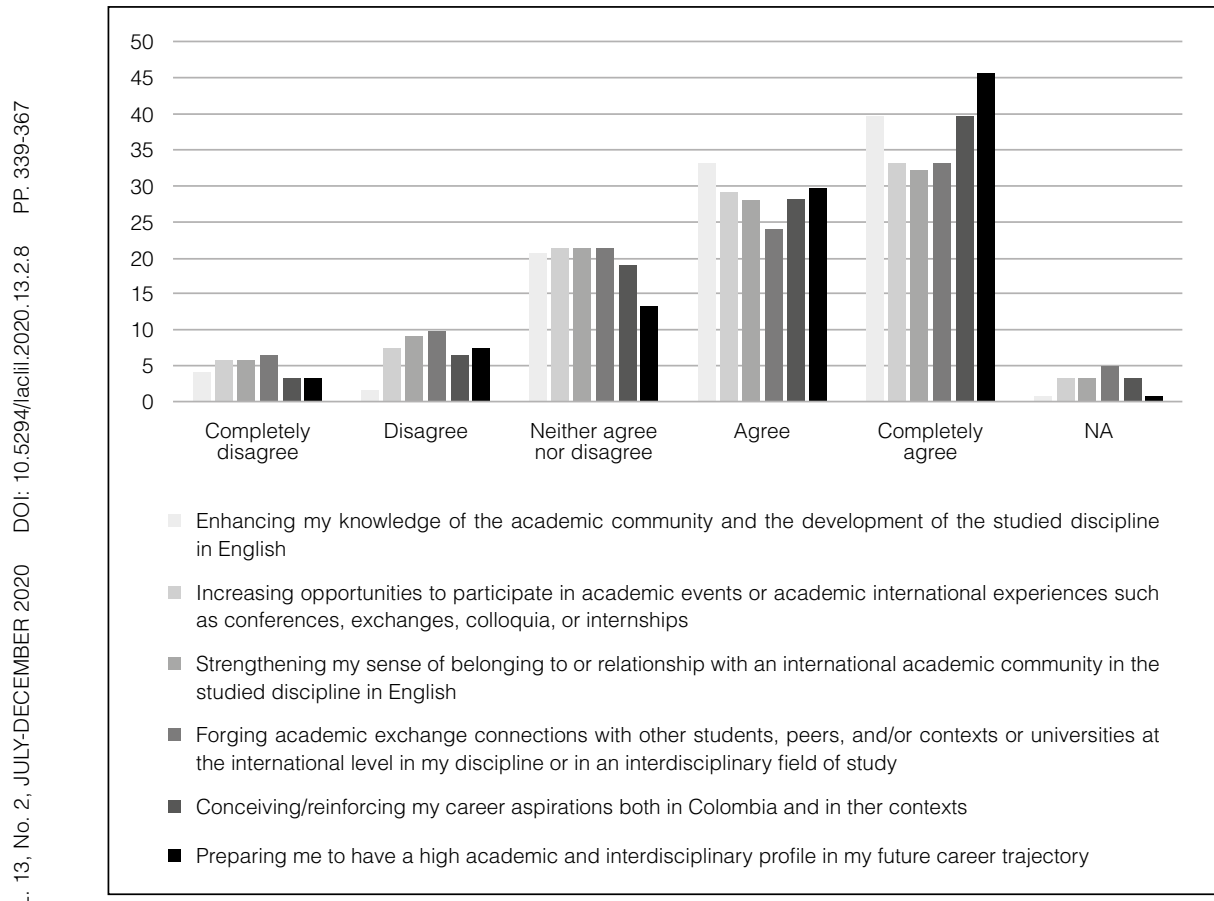

Source: Own elaboration.

\section{Institutional requirements: Global and local trends}

Participants often referred to EMI and internationalization initiatives as institutional requirements. Although they acknowledge the HEI's efforts to develop a sustainable EMI policy, they also express some concerns about how these initiatives are being introduced.

The faculty participants recognized that the University is working hard to achieve internationalization by means of incorporating English. F1 stated that "the university does a great job of bringing guest speakers, 
programs... research groups from all over the world, and usually... the working language, will be in English." Regarding the hiring of English-speaking faculty, F1 also said: "I think that [hiring English-speaking staff] in itself is an achievement because it's not something theoretical." F2 talked about the summer school programs offered by the university; particularly about how "many of these programs are led by invited international faculty," and how the organizing committee is "starting to call this initiative the 'International Summer School'." F2 also said that, while promoting the summer programs, the organizers "talk about the importance of taking English classes or about improving their English level" in order to be more prepared for the program.

The importance of EMI was widely discussed in the faculty and administrators' interviews as well as seen in many of the responses to open questions on the students' questionnaire. All groups of participants acknowledge the relevance of English to meet local and global academic and professional standards. Regarding the advantages of EMI programs at this HEI, F1 said:

I think that all students are benefiting from this, but in different ways... it's a good experience for vocabulary and also contact with other English speakers... it's also valuable to spend time interacting in English, [and] working in teams in English.

Many students also seem to recognize the importance of taking EMI courses not only to fulfil the university's language requirements but also to be up-to-date in their fields of study and future careers. When asked about their motivations for enrolling in the EMI course, almost one-third (27\%) of them reported that they needed to fulfil the requirement. However, other comments pointed to the advantages of taking English-taught courses: "I prefer courses in English because the literature is also in English"; "[I wanted to have] the opportunity to have my first experience of what could possibly be a future exchange [while I] acquired academic terms from my major in English"; and "[I want to] focus on finances in my professional career. In this area, the majority of key terms and concepts are in English. Therefore, I want to master this language." Many students, especially those majoring in business, reported that taking the EMI course was crucial for their future careers, especially because it was offered in English. 
While the students' comments presented in the previous paragraph do suggest that an important percentage of students (25\%) take EMI courses because they perceive them as advantageous for their academic fields, a very similar percentage (27\%) opts to study academic content through English merely for sake of practicing the language. Again, the students' lack of understanding about the introduction of EMI in this HEI is an indicator that top-down communication might not be serving its purpose at present.

Some participants also expressed concerns about the process of achieving internationalization and the successful implementation of an EMI initiative. When asked about the possibility of this HEI adopting EMI and L1 instruction equally, F1 stated: "I think that's a possibility, but we would need to invest... a lot of time... in some immersion programs because... unlike a bilingual school, we just don't have the contact hours at the moment." Regarding the same topic, A2 said: "I find it difficult to believe... First of all, [the students] are all adults. They come with different languages... [and] they are bilingual in French, in Italian, in German, in Portuguese, etc. Even if some have good English, I find it difficult to believe that this will be a bilingual university, like a bilingual school." Despite the strong presence of English in the institution, there is still some skepticism about this HEI becoming balanced bilingual in English and Spanish.

A critical view of how EMI in this HEI is being implemented also emerged in the data. F2, who explicitly said that "EMI is good," also calls for a deeper understanding of our national context and students' needs, stating:
I believe that we must... stimulate reflection about the importance of English in each faculty. Then, based on that reflection, we can decide which ways to follow for internationalization. Well, we talk about "English" and "Internationalization" as if they were both the same thing, but they are not... [we must think about] what is important... or what each faculty understands as "necessary" or "important"... or how useful internationalization is and what implications it has in terms of education and courses in other languages...

Contrastive perspectives about the role of English for the students' current studies and for their future careers also emerged in the interviews. First, A4 expressed that "the students think that it is necessary... but they are not aware of what they need to do... the fact that English is 
so important to perform academically in our university is not so clear [for them]". Nevertheless, A2 stated that "there are programs that, so far, have not needed English. Perhaps they will need it later on, but, for example, architecture or arts, not so much." In relation to the students' future, F2 said that for the student population that he serves "English is not that important... it's useful; he also added: "I try to portray it this way: something that is not necessary, but it can enhance their profiles." These contrasting perceptions suggest that not all participants seem to be clear about the purpose of EMI in this HEI and that their degree of involvement in institutional decision-making processes, as discovered in RQ1, might not be equal.

\section{Discussion}

The document review conducted reveals that English, and more specifically EMI, seems to symbolize internationalization for this HEI. Evidence of this emerged in the findings of RQ1, namely the establishment of an IO, the curriculum reforms, and the enhancement of ELL environments; all of these initiatives were undertaken in a relatively short period of time (2016-2017). The interview and questionnaire findings discussed in RQ1 and RQ2, on the other hand, revealed more diverse or even divergent points of view. While the role of English for academic and professional purposes in the lives of all of the participants and in this HEI was given considerable relevance, administrators and faculty addressed issues related to the English level of the students and the disproportionate presence of English in comparison with other languages. Also, although many students stated that they had enrolled in an EMI course to prepare for an exchange or to enhance their careers, about two thirds of them simply see it either as a part of ELL or as a regulatory requirement. These concerns and lack of understanding among the participants might suggest a lack of articulation between the internationalization initiatives and the implementation of EMI as an essential part of the process. This connection has also been argued as a misconception by de De Wit (2011) and Knight (2011), especially because it may jeopardize the heterogeneous, inter-national (referring 
to multiple nations), multilingual, and intercultural nature underlying internationalization processes (Teasdale, 2017; Dafouz \& Smit, 2020).

Despite the benefits of EMI highlighted by some authors (Martinez, 2016; Macaro, 2018), the literature also shows a number of critiques of this approach in HEIs. Some of these include: insufficient English skills of professors and students, threats to content learning via English as a second or third language, low achievement in tests due to poor English skills, and the superimposition of English over other languages (Shohamy, 2013). Although none of the participants mentioned poor language skills among faculty teaching EMI courses, the faculty participants did express their concerns about the low level of English language skills and unpreparedness of some students. The strong presence of English as opposed to that of other languages was also discussed by the administrators and faculty in their interviews. Thus, it is crucial for an EMI top-down strategy within internationalization and, more specifically, within IaH, to be supported by other formal and informal institutional initiatives and curricular adjustments (Knight, 2004; Beelen \& Jones, 2015). HEIs must consider the local constraints and view internationalization as a process rather than disconnected activities (de Wit, 2011). This was directly stated by A3 as one major concern within the IO practices. This HEI's EMI initiative is framed within a systemic curriculum transformation. Acknowledging the participants' perceptions is crucial, as this will aid in promoting contextualized EMI practices that target the HEI's needs, faculty profiles, and expectations to formulate clear policies in the long run (Macaro et al., 2018).

It was evidenced that the participants embrace diverse views about English, bilingualism, and multilingualism. These views provided varying perceptions of the EMI initiative; however, overall, it is rather seen as something necessary and inevitable in a globalized Colombian academia, as also highlighted by Corrales et al. (2016). The students tended to predominantly associate EMI within an EAP framework, which recalls traditional practices of L2 learning. Interestingly, in this HEI, EMI emerges as a content-driven experience where students are expected to build knowledge using their linguistic repertoires from an English-based input. Moreover, their imaginaries and identities seem marked by their immediate contexts, needs, and socio-cultural practices (Omoniyi \& White, 2006) in which English is ubiquitous. This 
concurs with the administrators and faculty, who maintained that the languages they use, including English, define them and configure their practices, affiliations, and fields of study.

This study paves the way for future research about EMI in HEIs and the development of contextualized EMI guidelines within Latin American HEIs in the internationalization era. Findings derived from this study imply that EMI is inevitable in this region; however, a sustainable EMI strategy requires substantial articulation amongst its participants in relation to concrete actions, such as the co-creation of guidelines and objectives as well as the consideration of the students' realities, needs, and expectations. Further studies could focus on ways to convey such articulation, as well as on trans-national EMI initiatives, implementation, classroom practices, and also on inquiring about the role of (Latin American) local languages and cultural backgrounds within an internationalization policy.

\section{Acknowledgements}

This research was supported by the Vicerrectoría de Investigaciones and Facultad de Ciencias Sociales at Universidad de los Andes (Colombia). We wish to thank Alejandro Mejía and Gabriela Suárez for their support. Also, we are grateful to Anne-Marie Truscott de Mejía, Emilia Cedercreutz, and Caitlin May for their comments and input.

\section{References}

Airey, J. (2016). Content and language integrated learning (CLIL) and English for academic purposes (EAP). In K. Hyland \& P. Shaw (Eds.), Routledge handbook of English for academic purposes (pp. 71-83). Routledge.

Altbach, P., \& Knight, J. (2007). The internationalization of higher education: Motivations and realities. Journal of Studies in International Education, 11(3-4), 290-305. https://doi.org/10.1177/1028315307303542 
Barkhuizen, G., Benson, P., \& Chik, A. (2013). Narrative inquiry in language teaching and learning research. Routledge. https://www.routledge.com/ Narrative-Inquiry-in-Language-Teaching-and-Learning-Research/ Barkhuizen-Benson-Chik/p/book/9780415509343

Beelen J., \& Jones E. (2015) Redefining internationalization at home. In A. Curaj, L. Matei, R. Pricopie, Salmi J., \& P. Scott (Eds.). The European higher education area (pp. 59-72). Springer.

Bonilla, C. A., \& Tejada-Sanchez, I. (2016). Unanswered questions in Colombia's foreign language education policy. Profile Issues in Teachers' Professional Development, 18(1), 185-201. https://doi.org/10.15446/profile.v18n1.51996

Braun, V., \& Clarke, V. (2006). Using thematic analysis in psychology. Qualitative Research in Psychology, 3(2), 77-101. https://doi. org/10.1191/1478088706qp063oa

Corrales, K. A., Rey, L. A. P., \& Escamilla, N. S. (2016). Is EMI enough? Perceptions from university professors and students. Latin American Journal of Content \& Language Integrated Learning, 9(2), 318-344. https://doi.org/10.5294/laclil.2016.9.2.4

Cohen, L., Manion, L., \& Morrison, K. (2007). Research methods in education. Routledge.

Cronquist, K., \& Fiszbein, A. (2017). El aprendizaje del inglés en América Latina. https://www.thedialogue.org/wp-content/uploads/2017/09/ El-aprendizaje-del-ingl\%C3\%A9s-en-Am\%C3\%A9rica-Latina-3.pdf

Crystal, D. (2003). English as a global language. Cambridge University Press.

Dafouz, E., \& Smit, U. (2020). ROAD-MAPPING English medium education in the internationalised university. Palgrave Macmillan.

De Wit, H. (2011). Trends, issues and challenges in internationalisation of higher education. Centre for Applied Research on Economics and Management, Hogeschool van Amsterdam.

Duong, V. A., \& Chua, C. S. K. (2016). English as a symbol of internationalization in higher education: A case study of Vietnam. Higher Education Research \& Development, 35(4), 669-683. https://doi.org/10.1080/0 7294360.2015 .1137876

Education First (EF). (2017). English proficiency index - indice del dominio del inglés de EF. www.ef.com/epi

Gacel-Ávila, J. (2003). La internacionalización de la educación superior. Paradigma para la ciudadanía global. Universidad de Guadalajara. 
Gazzola, A. L., \& Didriksson, A. (2008). Tendencias de la educación superior en América Latina y el Caribe. https://beu.extension.unicen.edu.ar/xmlui/handle/123456789/305

Hamp-Lyons, L. (2011). English for Academic Purposes. In E. Hinkel (Ed.), Handbook of research in second language teaching and learning (pp. 89-105). Routledge.

Hellekjær, G. O. (2010). Language matters: Assessing lecture comprehension in Norwegian English medium higher education. In U. Smit, T. Nikula, \& C. Dalton-Puffer (Eds.), Language in CLIL Classrooms (pp. 233-258). John Benjamins Publishing.

Huang, Y.-P. (2018). Learner Resistance to English-medium instruction practices: A qualitative case study. Teaching in Higher Education, 23(4), 435-449. https://doi.org/10.1080/13562517.2017.1421629

Knight, J. (2004). Internationalization remodeled: Definition, approaches, and rationales. Journal of Studies in International Education, 8(1), 5-31. https://doi.org/10.1177/1028315303260832

Knight, J. (2011). Five myths about internationalization. International Higher Education (62), 14-15. https://doi.org/10.6017/ihe.2011.62.8532

Macaro, E., Curle, S., Pun, J., An, J., \& Dearden, J. (2018). A systematic review of English medium instruction in higher education. Language Teaching, 51(1), 36-76. https://doi.org/10.1017/S0261444817000350

Macaro, E. (2018). English medium instruction. Oxford University Press.

Martinez, R. (2016). English as a medium of instruction (EMI) in Brazilian higher education: Challenges and opportunities. In K. R. Finardi (Ed.), English in Brazil: Views, policies and programs (pp. 191-228). SciELO-EDUEL.

Merriam, S. B., \& Tisdell, E. J. (2015). Qualitative research: A guide to design and implementation. John Wiley \& Sons.

Ministerio de Educación Nacional (MEN) Colombia. (n.d.). Colombia Bilingüe. https://aprende.colombiaaprende.edu.co/es/colombiabilingue/86689

Morell, T., Alesón, M., Bell, D., Escabias, P., Palazón, M., \& Martínez, R. (2014). English as the medium of instruction: a response to internationalization. In M. T. Tortosa Ybáñez, J. D. Álvarez Teruel, \& N. Pellín (Eds.), Xarxes-Innovaestic 2014. Llibre d'actes. ICE de la Universitat d'Alacant. https://hdl.handle.net/10045/42431 
Novelli, M., \& Lopes Cardozo, M. T. A. (2008). Conflict, education and the global south: New critical directions. International Journal of Educational Development, 28(4), 473-488. https://doi.org/10.1016/j. ijedudev.2008.01.004

Omoniyi, T., \& White, G. (Eds.) (2006). The sociolinguistics of identity. Continuum.

Rizvi, F. (2007). Internationalization of curriculum: A critical perspective. In Hayden, M., Thompson, J., \& Levy, J. (Eds.), The Sage handbook of research in international education, 390-403.

Shohamy, E. (2013). A critical perspective on the use of EMI at universities. In A. Doiz, D. Lasagabaster \& J. M. Sierra (Eds.), English-medium instruction at universities: Global challenges (pp. 196-210). Multilingual Matters.

Stein, S., Andreotti, V., Bruce, J., \& Suša, R. (2016). Towards different conversations about the internationalization of higher education. Comparative and International Education/Éducation comparée et internationale, 45(1), 2.

Soren, J. K. (2013). Teacher identity in English-Medium instruction: Teacher cognitions from a Danish tertiary education context (Doctoral thesis). Copenhagen, Faculty of Humanities, University of Copenhagen.

Taylor, C. (2002). Modern Social Imaginaries. Public Culture, 14(1), 91-124. https://muse.jhu.edu/article/26276\#info_wrap

Teasdale, J. A. (2017). An alternative social imaginary for internationalization in universities (Doctoral thesis). Vancouver, Faculty of Education, Simon Fraser University.

Times Higher Education. (2019). Latin America University Rankings 2019. https://www.timeshighereducation.com/world-university-rankings/2019/latin-america-university-rankings\#!/page/0/length/25/ sort_by/rank/sort_order/asc/cols/undefined

Universidad de los Andes. (2016). Programa de desarrollo integral (PDI 20162020). https://planeacion.uniandes.edu.co/pdi/nuestro-pdi

Valencia-Cabrera, M. (2017). The construction of teacher candidates' imaginaries and identities in Canada, Colombia, and Chile: An international comparative multiple narrative case study (Doctoral dissertation). Toronto, University of Toronto.

Yin, R. K. (2009). Case study research: Design and methods. SAGE Publications. 